\title{
Analysis the Relationship of Entrepreneurship Education Learning with Creating Entrepreneurial Spirit Students in Telkom University
}

\author{
Dr. Djoko Murdowo \\ Faculty of Creative Industry \\ Telkom University \\ Indonesia \\ RizkaRachmawati \\ Faculty of Creative Industry \\ Telkom University \\ Indonesia
}

\begin{abstract}
This study aims to determine to which extent the right model of entrepreneurship education can create entrepreneurial spirit of Telkom University students. Data from the survey shows the interest and intention of large students to become entrepreneurs as the main asset. This study used qualitative methods by taking survey sample of 150 lecturers and students. The results show that an effective entrepreneurial learning model can be carried out through a curriculum, with the student-centered learning method (SCL), which supported by lecturers who have the competence in the field of entrepreneurship. The lecturers also need to create an entrepreneurial atmosphere by forming a start-up and entrepreneurship business forum, building partnership networks, working with investors and establishing entrepreneurial institutions or organizations.
\end{abstract}

Keywords: intention, entrepreneur, entrepreneurship education, higher education institution

\section{Introduction}

A country can be said to be a developed country if it has a minimum entrepreneurs number of 2 percent from its population. As an illustration, developed countries like the United States is having 12.5 percent entrepreneurs of the total population, as well as Japan with 10 percent, Britain with 10 percent, and Singapore with 7.5 percent. As for developing countries, there is China with 2.5 percent, India with 2.5 percent and Malaysia with 2.5 percent. Indonesia, which is said to be a new developing country has 0.2 percent number of entrepreneurs from its total population (Elfindri, et al, 2010).

To catch up with creating entrepreneurial buds that have the spirit of innovation and creativity can be started by fostering entrepreneurial interest through the collaboration of four sectors, namely government, business, civil society and intellectual (Oscar: 2010). Government has the role of encouraging and fostering the entrepreneurial spirit, through entrepreneurship education and the provision of adequate budgets (Nwachukwu, 2018).

Intellectuals driven by formal education, especially Higher Education Institution, have a dominant role in preparing graduates who are reliable and have entrepreneurial spirit. Government and intellectuals (in the world of education) actually have tried and collaborated with real actions, such as with the Decree of the Directorate General of Higher Education in 2009 which required universities to put entrepreneurship courses into the curriculum as compulsory courses for 2 semesters (Handriani, 2011).

Although currently universities in Indonesia have organized entrepreneurship education, it has not been fully able to foster intention and create entrepreneurial people who are creative, innovative and independent. Besides that, the interest and motivation of students for entrepreneurship is still low, which they prefer to be a job seeker. This cannot be separated from the learning process given, be it in the form of curriculum, non-curriculum, and an environment that has not been supportive in forming independent and entrepreneurial students.

The results of research and surveys of Telkom University students showed that 74.2 percent of students after graduation had an interest in owning a business independently. This shows that Telkom University students have the potential and intention to be developed and equipped with good knowledge, to be able to become reliable entrepreneurs through education. The problem above is quite interesting for the author to explore more deeply about how is the ideal implementation of entrepreneurship education in universities that can produce reliable entrepreneurs. 
For this reason, it is important to note several important aspects in this writing, such as 'how is the process, what are the material and what is the learning model like?', 'how to create a supportive learning environment?', and 'how much does the institution support the entrepreneurial learning process?'.

\section{Theoritical Background}

\subsection{Intention and Interest in Entrepreneurship}

Entrepreneurial intention is a great intention to run a business. According to Wijaya (2017), entrepreneurial intentions can be interpreted as intentions or desires that exist in a person to carry out an entrepreneurial action. Intention and interest to become entrepreneurs are influenced by the level of confidence and preference for risk that will be borne by someone when becoming an entrepreneur or an employee.

Everyone has a different level of confidence on whether by becoming entrepreneurs they can create jobs and accommodate the workforce. Besides that, there is also a preference for the risk of whether being an entrepreneur will have a bright future. Students who are afraid to take risks tend to choose to be a private employee, civil servant, or employee of BUMN (State Owned Enterprise) as a career choice, while for students who dare to take risks (risk takers) tend to choose to become an entrepreneur as a career choice (PrilRanto, 2016).

Entrepreneurial intentions and interests need to be cultivated to change the mindset of school graduates who have only wanted to become job seekers to become superior entrepreneurs. Various ways can be done in increasing interest in entrepreneurship, one of which is through education. Education is the most effective factor in improving and developing attitudes and entrepreneurial intentions, especially in universities. Zimmerer (1996), states that one of the factors driving the growth of entrepreneurship in a country lies in the role of universities through the implementation of entrepreneurship education.

\subsection{Entrepreneurship Education}

Entrepreneurship education is one of the factors in growing intentions, interests, and developing passion, soul and entrepreneurial behavior. According to Kuarilsky\&Waistrad (1998), education will shape entrepreneurs by increasing knowledge about business and forming psychological attribution as well as self-confidence, self-esteem and selfefficacy. Besides that, entrepreneurship education aims to shape students' attitudes, behaviors and intentions to become entrepreneurs. Research by Heinonen and Poikkijoki (2006) confirms that through entrepreneurship education, the entrepreneurial skills and attitudes possessed by each individual will be integrated through the process, so that an entrepreneurial behavior can be formed.

Entrepreneurship education in higher education institution is not only done through the curriculum, but it can also be done through non-curriculum supported by a conducive environment. Kasih (2013) describes several important aspects that must be considered in entrepreneurship education which include aspects in the curriculum and aspects outside the curriculum. The curriculum is a learning plan that students must complete to reach a certain level. Handaling (2012) states that the curriculum is a learning plan that involves all activities that must be taken or completed by students in order to reach a certain level.

Non-curriculum aspects are a learning activity outside the classics that support and enrich curriculum material. Susilaningsih (2012) emphasizes aspects outside the curriculum to support the success of entrepreneurship education in a higher education institution. Purwana and Sumiati's research (2016) have developed entrepreneurship education in terms of curriculum packaged in entrepreneurship courses and activities outside the curriculum that are related to creating students with entrepreneurial spirit.

Therefore, the learning process in entrepreneurship education must be able to encourage students to build interest in entrepreneurship, identify and capture opportunities, as well as decide and realize opportunities in the form of initiative behavior.

\subsection{Entrepreneurship}

Entrepreneurship can be said to be a scientific discipline, soul, and the ability to think creatively, behave innovatively and be able to create added value. As a scientific discipline, entrepreneurship learns about the values, abilities, and behavior of a person in facing life's challenges to obtain opportunities with various risks they may face (Suryana: 2006). Epistemologically, entrepreneurship can be interpreted as an ability to think creatively and behave innovatively that is used as a basis, resources, motivators, goals, tactics / strategies, and tips for dealing with life challenges (Hunger and Wheelen, 2003). According to Sukidjo (2011) entrepreneurship reflects enthusiasm, attitude, and behavior as role models in the courage to take calculated risks based on their own willingness and ability. 
On the other hand, entrepreneurship can be said as an effort to create added value (Siswoyo, 2009). The essence of entrepreneurship is creating added value through the process of combining various resources with different new ways, so it can be able to compete freely in the business market. Saeid Karimi et al (2016) reinforce the findings of Fayolle\&Gailly (2008) that entrepreneurship is basically intentional and planned behavior, which can increase economic efficiency, bring innovation to markets, create new jobs, and improve the quality of work. Entrepreneurship is also a creativity and innovation that is owned by college graduates to produce added value for themselves and benefit others / society, and bring mutual benefit.

\section{Research Methodology}

The research method used is qualitative research methods, with case studies on the process of entrepreneurship learning at Telkom University, which carried out through field observations and distributing questionnaires. This study uses a sample of the students who take entrepreneurship courses and the entrepreneurial lecturers. This segment was chosen to explore the needs and know the characteristics of students and lecturers that will be used as the subject of analysis. Besides that, data mining was also conducted on entrepreneurship education providers in the General Basic Education Program (PPDU) unit of Telkom University.

The method of data collection was carried out through surveys by distributing questionnaires to 150 respondents who explored the interests and desires of students after graduating, conducting interviews or question and answer related to the need for perceptions of entrepreneurship subjects, and field observations by observing activities and supporting entrepreneurial learning activities at Telkom University.

\section{Result and Discussion}

The intention and interest of students to become entrepreneurs after graduation is a capital and opportunity for universities to create the right learning model in equipping students to become superior entrepreneurs. Higher education plays a role in improving quality, superiority, and entrepreneurial spirit of human resources. There have been many efforts made by universities to foster an entrepreneurial spirit among students. However, the entrepreneurship education movement in universities has not been able to change the mind-set of college graduates from finding jobs (job seekers) to creating jobs (job creators).

Analysis of the entrepreneurship education learning process as an effort to develop student interest can be explored in the learning process through curriculum, reliable lecturer support, also through non-curriculum pathways, which is through building partnership networks and learning from successful business people. No less important is the support structure and commitment of the institution that is absolutely necessary.

\subsection{Entrepreneurial Intention and Interest}

Intention is the desire of someone to become an entrepreneur. For this reason, we need to measure the intention and interest of someone to become an entrepreneur. From the results of interviews and questionnaire dissemination to student respondents who took Entrepreneurship courses at Telkom University, they were asked about the level of trust and confidence if they became entrepreneurs, the results can be described as follows:

Figure 4.1: Survey result of trust and confidence level if students become entrepreneurs

\begin{tabular}{|c|l|c|c|}
\hline \multirow{2}{*}{ QUESTION INDICATOR } & \multicolumn{1}{|c|}{ ANSWER } \\
\cline { 3 - 4 } & \multicolumn{1}{|c|}{ YES } & NO \\
\hline 1 & Being an entrepreneur can create jobs rather than looking for jobs. & $88.7 \%$ & $11.3 \%$ \\
\hline 2 & $\begin{array}{l}\text { Entrepreneurship can accommodate labor and reduce unemployment, and have a } \\
\text { good and bright future. }\end{array}$ & $89.5 \%$ & $10.5 \%$ \\
\hline 3 & Entrepreneurship is more challenging than being an employee. & $85.5 \%$ & $14.5 \%$ \\
\hline 4 & After graduation, I want to be a tough entrepreneur. & $74.2 \%$ & $25.8 \%$ \\
\hline
\end{tabular}

From the data of the questionnaire, it appears that over $80 \%$ of respondents believe that being an entrepreneur can create jobs, reduce unemployment, have a good future and be more challenging than being an employee. One of the questions conveyed is related to intention after graduation, it turns out $74.2 \%$ students want to be tough entrepreneurs. Besides that, in the questionnaire also asked about what values were to be obtained by student if later they become an entrepreneur, the results are described as follows: 
Figure 4.2 Survey result of values to be obtained by students if they become entrepreneurs

\begin{tabular}{|c|l|c|c|}
\hline \multirow{2}{*}{ QUESTION INDICATOR } & \multicolumn{2}{|c|}{ ANSWER } \\
\cline { 3 - 4 } & \multicolumn{1}{|c|}{ YES } & NO \\
\hline 1 & $\begin{array}{l}\text { Entrepreneurship can make us creative, innovative, independent, and practice } \\
\text { honesty, and can increase self-esteem. }\end{array}$ & $91.1 \%$ & $8.9 \%$ \\
\hline 2 & Entrepreneurship can give an example of hard work, not giving up easily. & $90.3 \%$ & $9.7 \%$ \\
\hline
\end{tabular}

Survey data shows that almost $90 \%$ of respondents said that entrepreneurship can shape the spirit with creative, innovative, independent and honest values. Besides that, there is a belief that entrepreneurship can increase trust, selfesteem, work ethic and an unyielding attitude.

The survey results above have shown a good measure of the level of trust and great intention about the benefits of being an entrepreneur and the value obtained as an entrepreneur. Entrepreneurial intentions and interests need to be maintained and grown by students, so that after graduating from university they can become superior entrepreneurs. This is in accordance with Wibowo's research (2014) that entrepreneurial intentions prove to be the best predictor of entrepreneurial behavior and can be used as a reasonable basic approach to understanding who will become an entrepreneur.

Education plays a very important role in improving and developing entrepreneurial attitudes and intentions. For this reason, it is necessary to make an entrepreneurial learning model in higher education institution both on the curriculum and non-curriculum side.

\subsection{Curriculum}

The curriculum as a reference in conducting lectures will be used as a reference for lecturers and students in the learning system. A well-designed and appropriate curriculum will provide optimal learning output. What is the number of Semester Credit Units (SCU), as well as the methods and materials that must be applied, become material that must be discussed:

\section{a. The number of Semester Credit Units (SCU) and Semester}

Higher education institution have included entrepreneurship courses in learning curricula with intensity, varying number of credits (SCU), and stand-alone courses or deposited in relevant subjects.

As a study material to determine the adequacy of time, number of credits (SCU), learning methods and material or learning content, a survey was conducted through a questionnaire. The questionnaire results for Telkom University students are as follows:

Figure4.3 :Survey result of the amount of time and number of credits of entrepreneurship course

\begin{tabular}{|c|l|c|c|}
\hline \multirow{2}{*}{ QUESTION INDICATOR } & \multicolumn{1}{|c|}{ ANSWER } \\
\cline { 3 - 4 } & \multicolumn{1}{|c|}{ YES } & NO \\
\hline 1 & $\begin{array}{l}\text { The amount of time for one entrepreneurial learning and the amount of 2 credits is } \\
\text { sufficient. }\end{array}$ & $56.5 \%$ & $43.5 \%$ \\
\hline 2 & $\begin{array}{l}\text { The number of credits suitable for entrepreneurship courses is 3 to 5 credits, and is } \\
\text { given in the fifth semester. }\end{array}$ & $44.4 \%$ & $55.6 \%$ \\
\hline
\end{tabular}

From the results of the questionnaire above, it can be said that respondents consider that the time and number of credits (SCU) for entrepreneurship learning should be a stand-alone course and should be given in two credits only. If it is given in more than 2 credits, as much as $55.6 \%$ of respondents disagree. However, some respondents agreed to learn it in the fifth semester and above. Higher education institutions in Indonesia generally have entrepreneurship courses, although with different intensity and number of credits. In fact, not all departments are presenting entrepreneurship education in a stand-alone curriculum, some are entrusted to relevant courses because the number of available credits is felt to be inadequate to add other subjects outside the curriculum target.

Referring to the Telkom University study case, entrepreneurship courses are placed as a stand-alone course and given to all majors or study programs, with the total of 2 credits in the fifth semester. Management of courses is managed centrally by the General Basic Education Program (PPDU), not carried out in each Faculty. The management by PPDU includes scheduling, lecturer allocation, investor search, assessment and others. It can be said that the management of entrepreneurship learning in Telkom University has been included in a stand-alone curriculum given to all majors not only for certain faculties/ departments, and also allocated in the form of adequate credits of 2 credits given in the fifth semester. This is in accordance with research by Nteere (2012) who recommended the time used for entrepreneurship learning is 2 to 3 hours for one meeting. 
Curriculum management is carried out centrally at Telkom University with the aim of making it easier in planning, supervision, evaluation and implementation. This conformity needs to be tested again, especially about the learning methods and materials, whether they have met and are in line with expectations or not.

\section{b. Methods and Materials of Entrepreneurship Curriculum}

Entrepreneurship learning methods play an important role in entrepreneurship education. Besides that, entrepreneurial material should be packaged in order to foster students' interest in entrepreneurship. The results of the questionnaire regarding students' perceptions of entrepreneurial learning methods and materials are as follows:

Figure4.4 :Survey result of method and material of entrepreneurship course

\begin{tabular}{|c|l|c|c|}
\hline \multirow{2}{*}{1} & \multicolumn{1}{|c|}{ QUESTION INDICATOR } & \multicolumn{2}{|c|}{ ANSWER } \\
\cline { 3 - 4 } 1 & $\begin{array}{l}\text { Entrepreneurship learning method through a learning approach that places students } \\
\text { in a more active role, while the lecturer acts more as a facilitator. }\end{array}$ & $69.4 \%$ & $30.6 \%$ \\
\hline 2 & $\begin{array}{l}\text { The teaching of entrepreneurship should not be focused on the cognitive domain } \\
\text { only, but also accompanied by "experiencing" activities as well as practice. }\end{array}$ & $81.4 \%$ & $18.6 \%$ \\
\hline 3 & $\begin{array}{l}\text { Entrepreneurship material is designed in real business where students make } \\
\text { business plans, pitching, and access to capital, through product production, selling, } \\
\text { calculating costs, and evaluating. }\end{array}$ & $83.9 \%$ & $16.1 \%$ \\
\hline
\end{tabular}

From the results of the questionnaire above it can be said that $69.4 \%$ of respondents consider that the method of entrepreneurship learning has been carried out through a learning approach that places students in a position that plays a more active role, while the lecturer plays a role as a facilitator. At the same time, there are still $30.6 \%$ of respondents who say that this is not optimal, it shows that there are still many students who consider this learning method does not fully involve the active role of students. Besides that, respondents agreed $(81.4 \%)$ that teaching entrepreneurship should not be focused on cognitive domains only, but also accompanied by "experiencing" activities and practices.

The results also showed that the majority of respondents (83.9\%) agreed, that entrepreneurship material was designed in a real business model where students made business plans, pitching, and access to capital, through product production, selling, calculating costs, and evaluating activities. Reflecting on the survey results above, this is a challenge for Telkom University to make improvements in entrepreneurial learning methods and materials.

Learning methods should not be designed in a one-way learning approach and lecturer-centered, as well as many cognitive theories or learning. This approach is less effective in encouraging students to be actively involved in building knowledge, attitudes and behavior (Afiatin, 2007) or it is also difficult to fulfill student softskill competencies (Widjanarko, et al, 2012). Wibowo, A (2017) stated that the teaching of entrepreneurship should not be focused on the cognitive domain alone, but also accompanied by practical activities.

Alternatives to increasing student involvement and active role in entrepreneurship courses can be done through studentcentered learning (SCL) approaches. The SCL approach is expected to be able to place students in a more active role, while the lecturer is more of a role as a facilitator. Afiantin (2007) states that the approach of the SCL learning method can be done through information sharing (information sharing), learning from experience (experience based), and problem solving (problem solving based). This corresponds to the research of Kasih (2013) which states that the use of student-centered learning methods is highly recommended, as part of the learning process to form graduates who have entrepreneurial spirit.

Efforts to increase the effectiveness of learning with information sharing methods need to be done by brainstorming, group discussion and collaboration. Besides that, learning methods from the experiences of other people who have been successful, real experiences from outside the campus and direct practice in the business world and industry need to be improved. As stated by Wiratno (2012) that these things can be done by increasing the education implementation effectiveness of link and match at the higher education level by carrying out initiatives to convert the existing entrepreneurial knowledge in the Business World and Industrial World (DUDI) to the academic community.

Improvements in entrepreneurial material can be designed in a real business where students are taught to make business proposals, produce products, sell products, calculate costs and conduct evaluations. This activity aims to shape the students mindset in entrepreneurship. Students are taught to focus on the process from starting a business plan, product prototype, pitching, to evaluation. 


\subsection{Competencies Support of Reliable Lecturer}

The obstacles faced by higher education institutions including Telkom University are the availability and ability/ competence of teaching staff/ lecturers who will take care of entrepreneurial courses. The description of the survey results of the respondents are as follows:

Figure 4.5: Survey result of entrepreneurship lecturers competencies

\begin{tabular}{|c|l|c|c|}
\hline \multirow{2}{*}{ QUESTION INDICATOR } & \multicolumn{2}{|c|}{ ANSWER } \\
\cline { 3 - 4 } & & \multicolumn{1}{|c|}{ YES } & NO \\
\hline 1 & Lecturers have knowledge and well-understanding about entrepreneurship material. & $84.7 \%$ & $15.3 \%$ \\
\hline 2 & Lecturers give motivation to increase my interest in entrepreneurship. & $76.6 \%$ & $23.4 \%$ \\
\hline
\end{tabular}

The description of the survey results is related to the lecturer's competency, respondents perceive that $84.7 \%$ of lecturers have good knowledge and understanding of material about entrepreneurship. However, only $76.6 \%$ of lecturers gave motivation to increase student's interest in entrepreneurship. This indication is an opportunity for Telkom University to increase the adequacy and competency of entrepreneurship lecturers.

To get maximum results in entrepreneurship courses, the lecturers must have entrepreneurial competencies and abilities. Entrepreneurship lecturers should have a creative spirit, able to create learning methods and models that are not only focused on theory but also enhance student intention.

Some alternatives that can be done to improve the capabilities of entrepreneurial lecturers include: the chosen lecturer must have competence in the field of entrepreneurship so that he/ she is able to take care of the entrepreneurial courses properly. In order to be able to hold entrepreneurial education courses, lecturers should try to understand the nature of entrepreneurial learning and have a strong motivation to acquire and develop their competencies, especially in the field of entrepreneurship. In addition, the improvement of lecturer skills can be done through training and participating in various entrepreneurship seminars, this will help increase the insight of lecturers, which can then be applied in the teaching process.

To overcome the availability of lecturers, higher education institutions can assign part-time lecturers or extraordinary (LB) lecturers. If that is the case, the higher education institution should choose lecturers who have a business or at least have experience in running a business, so that they can share their experiences with students in terms of entrepreneurship. Besides that, entrepreneurship lecturers can also be taken from business practitioners or professionals who have the time and willingness to teach and share their business experiences with students.

\subsection{Non-curriculum Entrepreneurial Activities}

Non-curriculum activities are activities outside the process of classical education, but more oriented towards activities that support entrepreneurial learning. For this reason, a supportive and mutually reinforcing environment is needed, such as building partnership networks with industry, alumni, market access and investors.

a. Building networks and partnerships

To measure how much effort has been made to build networks with partners, surveys are conducted with the following results:

Figure 4.6 : Survey results of non-curriculum entrepreneurial activities

\begin{tabular}{|c|l|c|c|}
\hline \multirow{2}{*}{ QUESTION INDICATOR } & \multicolumn{2}{|c|}{ ANSWER } \\
\cline { 2 - 4 } & YES & NO \\
\hline 2 & $\begin{array}{l}\text { The campus builds networks and cooperates with the business world for student's } \\
\text { practice or internships. }\end{array}$ & $66.1 \%$ & $33.9 \%$ \\
\hline 3 & $\begin{array}{l}\text { The university cooperates with industry in entrepreneurial activities. } \\
\text { The campus works with alumni who have been successful, so this opens } \\
\text { opportunities for students to draw success stories in the alumni industry. }\end{array}$ & $29.8 \%$ & $70.2 \%$ \\
\hline 4 & $\begin{array}{l}\text { The university collaborate with financial institutions, both banking and non- } \\
\text { banking, so that students who will start their business can be given convenience in } \\
\text { accessing business capital. }\end{array}$ & $65.1 \%$ & $34.9 \%$ \\
\hline 5 & $\begin{array}{l}\text { The university sends students for entrepreneurial activities initiated by the } \\
\text { government. }\end{array}$ & $68.0 \%$ & $32.0 \%$ \\
\hline
\end{tabular}

The survey results illustrate that Telkom University have tried to build networks, partnerships and cooperation with the business world, but $33.9 \%$ of respondents still feel that the campus has not been fully able to build partnerships with the business world for student practices and internships. 
Related to building partnerships with alumni as well as financial and capital institutions, it shows that $71.8 \%$ of respondents perceive the institution has succeeded in cooperating with alumni. However, 34.9\% of respondents considered that the partnership built on financial institutions as access to capital was still perceived as lacking. Regarding cooperation with government, there are still $32 \%$ of respondents who say that the institution has not fully included students in entrepreneurial activities initiated by the government.

The survey results are suggestions for improving business partnerships and collaboration with the business world and alumni. Kasih (2013) stated that cooperation with the business world was aimed for improving the quality of lecturers/ students, opening opportunities for business internships and opening opportunities for business cooperation especially for students. The concept of entrepreneurship learning at Telkom University currently teaches students about business planning, selling and seeking capital. Capital access is given by FAST (Telkom University Alumni Forum) as an investor, preceded by a presentation in the form of pitching. If it is feasible, the capital will be given. Besides that, in Telkom University, institutions from internal groups has been formed which aims to finance the entrepreneurial activities of students, they are the Telkom Education Foundation and the Telkom Group. However, access to capital that only relies on the capital from internal partners is not enough, so that it needs to be expanded. One of the ways is the collaboration with successful alumni needs to be developed and improved, so that students could get to draw success stories in the alumni industry. This is also a manifestation of alumni's concern for the alma mater, which psychologically has a closer emotional relationship to the fellow alumni.

The development of capital access can be further enhanced by banks and the government. Collaboration with the government, in this case the Directorate of Higher Education (DHE) needs to be improved and facilitated. The Ministry of Education and Culture through DHE has developed a Student Entrepreneur Program which includes the following programs: Entrepreneurship Education (PMW), Entrepreneurship Lectures (KWU), Entrepreneurship Internships (MKU), Business Work Lectures (KKU), Coorperative Education (Co-op) and business incubator (INBIS), that supports to produce graduates who are ready for work and job creators (Directorate General of Higher Education, 2010). Higher education institutions can be more proactive in encouraging and facilitating students to appear in programs planned by the DHE.

\section{b. Learn from successful business people}

Seminars and workshops on entrepreneurship and sharing from experts and successful business people are learning media that are based on real practice. To measure how much effort has been made in the context of learning through seminars and sharing with successful business people, a survey is conducted with the following results:

Figure 4.7: Survey result of entrepreneurship learning through seminar and sharing

\begin{tabular}{|c|l|c|c|}
\hline & \multicolumn{1}{|c|}{ QUESTION INDICATOR } & \multicolumn{2}{|c|}{ ANSWER } \\
\cline { 3 - 4 } & \multicolumn{1}{|c|}{ YES } & NO \\
\hline 1 & $\begin{array}{l}\text { The seminars and workshops conducted are in accordance with entrepreneurial } \\
\text { material. }\end{array}$ & $66.1 \%$ & $33.9 \%$ \\
\hline 2 & Invite entrepreneurs and business people to campus as role models. & $72.4 \%$ & $27.6 \%$ \\
\hline 3 & $\begin{array}{l}\text { If we want to invite entrepreneurs and businessmans who can inspire you to train } \\
\text { your entrepreneurial spirit, who do you recommend? }\end{array}$ & $\begin{array}{l}\text { Obtained several names } \\
\text { and sectors. }\end{array}$ \\
\hline
\end{tabular}

The results of the survey above illustrate that Telkom University has made the learning process not only classical, but also conducted learning in the form of seminars and workshops. However, there are still $33.9 \%$ of respondents which states that the material is still not in line with entrepreneurship. Seminars are usually conducted by inviting successful entrepreneurs as role models expressed by $72.4 \%$ of respondents. However, some respondents stated that the expertise of the speakers was not suitable as a resource person or role model. To get preferences from several experts or role models, open statements are made of who are entrepreneurs and businessmans who can inspire students to train their entrepreneurial spirit. From the questions, several names were recommended by respondents.

As a follow up to the survey results, Telkom University will expand the scope of seminar and workshop materials by inviting prominent figures who are successful in entrepreneurship. The entrepreneurship education model is also carried out by learning from "success stories" of successful entrepreneurial figures as motivators, and inspiration for students who want to become entrepreneurs later. The results of Murtini (2011) study, learning media related to learning from successful entrepreneurship can still be done without face-to-face meetings. Learning can also take the form of films or videos which are packaged on CDs containing "success stories", slide teaching materials with power point programs, and entrepreneurial textbooks. These things can be prepared to accommodate students who have different vision, hearing and capture potential. Entrepreneurship seminars and sharing can be done by inviting successful business people or entrepreneurs recommended by respondents. 
Institutions can present national and international entepreneurs as expected by respondents such as Rachel Ven (Instragram celebrity), Arif Muhammad (Twitter celebrity), Ahmad Zaky (Bukalapak), NadiemMakarim (Go-Jek) William Tanuwijaya (Tokopedia), Chris Feng (Shopee), Jack Ma (Alibaba), ChairulTanjung (CT Corp), Niko Al Hakim (Taichan Satay), Gibran Rakabuming (Entrepreneur), etc.

\subsection{Support and Commitment of Higher Education Institution}

Commitment and support of higher education institution management are needed for the process and direction of student's entrepreneurship development. Support for facilities, infrastructure and no less importantly, institutions, organizations or units that fully oversee entrepreneurial activities are also needed.

\section{a. Activities Container and Entrepreneurial Atmosphere/ Academic Entrepreneurship}

To measure how much the institution supports and provides a forum for developing entrepreneurship, a survey is conducted with the following results:

Figure 4.3: Survey result of campus support for its student entrepreneurship development

\begin{tabular}{|c|l|c|c|}
\hline \multirow{2}{*}{} & \multicolumn{1}{|c|}{ QUESTION INDICATOR } & \multicolumn{2}{|c|}{ ANSWER } \\
\cline { 2 - 3 } & \multicolumn{1}{|c|}{ YES } & NO \\
\hline 1 & $\begin{array}{l}\text { Campus establishes entrepreneurial institutions or organizations as a forum for } \\
\text { various activities related to campus entrepreneurship development. }\end{array}$ & $75.0 \%$ & $25.0 \%$ \\
\hline
\end{tabular}

The survey result above shows that $75 \%$ of respondents stated that university has formed entrepreneurial institutions or organizations as a forum for various activities related to campus entrepreneurship development. However, there is still a quarter of respondents who stated that the establishment of the forum was not fully optimal.

As a form of commitment, the institution not only provides a broader forum, but also needs to create an entrepreneurship atmosphere or academic entrepreneurship within the campus. Building an entrepreneurial atmosphere is another important aspect needed in the implementation of entrepreneurship education in higher education (Kasih, 2013). The entrepreneurial atmosphere is an atmosphere that was deliberately created by higher education institutions to support the implementation of entrepreneurship education as an effort to create an environment that supports stimulation of entrepreneurial behavior for each member, organizational structure and institutions within it (Ardiansyah, 2011).

Things that higher educations can do to support the process of implementing entrepreneurship education are:

- Make a container of startup and entrepreneurship business

There needs to be a container, forum, or program to accommodate the creative and innovative works of students to be able to become profitable businesses. The container can be called a Startup Business and Entrepreneurship Center, as a place to oversee and manage various entrepreneurial activities of students and lecturers, where students are guided and directed to the real world, as commercial science-based entrepreneurs. This container will also be a facilitator and mediator with external parties (stakeholders) to establish and develop cooperation for further development of entrepreneurial activities on campus (Kasih, 2013). This container is expected to help improve student competencies to enter increasingly competitive employment. Entrepreneurship courses can be expanded with the concept of internships, or visits and studies on startup business.

- Establish an entrepreneurial institution or organization

Establishing an entrepreneurial institution or organization within a university as a place for entrepreneurship education is very important. This institution or organization can be a forum for various activities related to campus entrepreneurship development. The form of the institution can be the Entrepreneurship Center, Entrepreneurship UKM (Student Activity Unit), or the Student Business Community at the student level. This institution or organization must have a clear and sustainable work program so that the entrepreneurial atmosphere strongly supports the achievement of entrepreneurial education goals.

- Entrepreneurship spirit development in the campus dormitory

Campus policy stipulates that first-year students at Telkom University are required to stay in the campus dormitory. This can be used as an opportunity and area of entrepreneurial spirit development from the beginning. The dormitory can be used as a place for developing soft skills in the field of entrepreneurship that will be carried out since students entered the dormitory, which is through the dormitory soft skill development program.

\section{b. Organizational unit that supports entrepreneurial activities}

As a higher education institution, that manages students with large student bodies, the existence of a permanent organizational structure and focus on managing entrepreneurial activities. How big the institution facilitates is measured through the questionnaire as follows: 
Figure 4.4 : Survey result of campus organizational unit that supports entrepreneurial activities

\begin{tabular}{|c|l|c|c|}
\hline \multirow{2}{*}{ QUESTION INDICATOR } & \multicolumn{2}{|c|}{ ANSWER } \\
\cline { 2 - 4 } & \multicolumn{1}{|c|}{ YES } & NO \\
\hline 1 & $\begin{array}{l}\text { The campus has a unit or organization that has the main tasks and functions as } \\
\text { managers who oversee entrepreneurial activities. }\end{array}$ & $72.5 \%$ & $27.5 \%$ \\
\hline 2 & $\begin{array}{l}\text { The campus provides support for facilities and infrastructure to oversee } \\
\text { entrepreneurial activities. }\end{array}$ & $71.7 \%$ & $28.3 \%$ \\
\hline
\end{tabular}

The survey results show that there is support from institutions related to units or organizations that structurally oversee entrepreneurial activities, but there are still $27.5 \%$ of respondents who state that this has not been done.

Currently Telkom University is institutionally committed to developed entrepreneurship. This can be shown by Telkom University core value of PRIME (Professionalism, Recognition of achievement, Integrity, Mutual respect, Entrepreneurship), as a guide for the entire academic community. One of the corevaluesis Entrepreneurship, which is determined as institutional value that will be applied by all stakeholders, shows the institute's commitment. Unfortunately, in reality there are still those who perceive that it is not optimally applied. For this reason, it is necessary to elaborate on the entepreneurship core values that are derived into a detail practice activities. Although Telkom University has formed a structural institution, the Character Development \& Entrepreneurship Manager, which focuses on developing and developing entrepreneurship at Telkom University, but it still needs to be empowered. Some of the things that need to be done are:

- Building synergy between the role of learning managed by PPDU and the Character Development Unit related to financing.

- More networks should be established with formal institutions such as government, foundations and financial institutions to access capital.

- Hold competition and workshop activities.

- Provision of adequate facilities and infrastructure.

\subsection{Entrepreneurship Education Learning Model}

The amount of intention and interest of students to become entrepreneurs is a very important aspect in determining the learning process in higher education institution. From the discussion above, the learning model of entrepreneurship education should be made in an independent curriculum, have 2 to 3 credits, given in the fifth semester, and supported by lecturers who have capability and entrepreneurial competence.

In non-curriculum activities, institutions need to build networks and partnerships with businessmans, investors, alumni and the government. In addition, it is also necessary to create an entrepreneurial atmosphere within the campus that is part of academic entrepreneurship such as the establishment of entrepreneurial institutions and entrepreneurial soft skills on campus.

To produce graduates who are entrepreneurial in spirit, there needs to be support from institutions, both structures and units that are clear and focus on handling entrepreneurial activities. Fulfillment of infrastructure facilities by the institute will also support the success of the learning process. 
Picture 4.1 Entrepreneurship education learning model

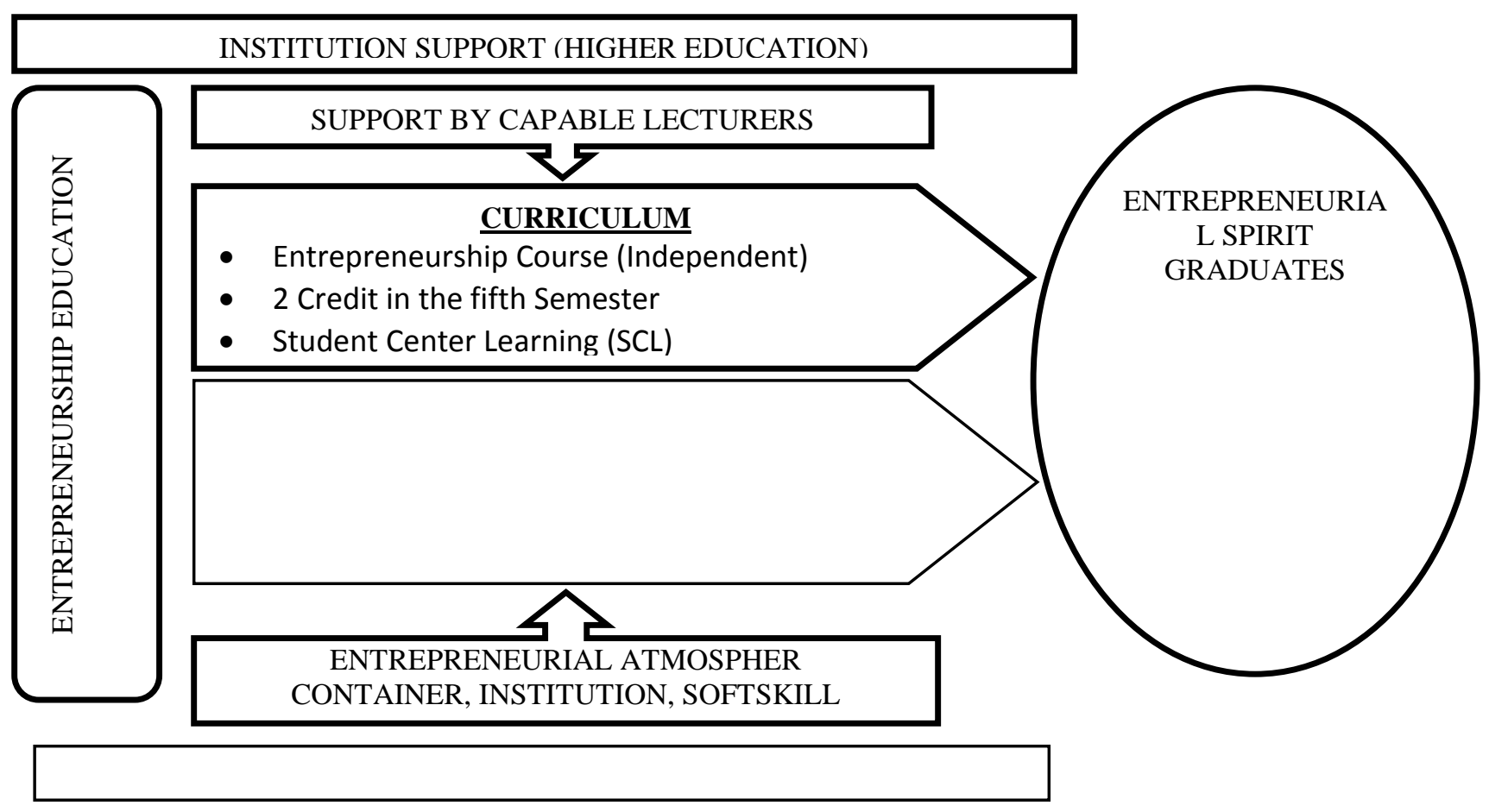

\section{Conclusion}

The implementation of entrepreneurship education in higher education institution can be effective by doing the following steps:

First, the entrepreneurship curriculum is given to all study programs as general subjects with an allocation of 2 credits. Entrepreneurship learning method should be done through student-centered learning (SCL) approach that places students in more active position, while lecturers being more like facilitators.

Second, the selection of teaching staff / lecturers who have competence in the field of entrepreneurship can be done by combining internal lecturers with external teaching staff (entrepreneurs and professional practitioners). If the institution want to take part time lecturers or extraordinary (LB) lecturers, then choose a lecturer who has a business or at least has experience in running a business.

Third, for the non-curriculum aspect, it needs to create an entrepreneurial atmosphere to support the implementation of entrepreneurship education in universities. This can be done by forming a startup and entrepreneurship business forum, building partnership networks, working with investors and establishing entrepreneurial institutions or organizations. Fourth, it needs support and commitment from higher education management, be it in terms of facilities, infrastructure, and organizations that fully oversee entrepreneurial activities.

\section{References}

Afiatin, Tina. 2007, "PembelajaranBerbasis Student - Centered Learning", http://inparametric.com/, diakses pada 20/2/2019.

Elfindri, DesriAyunda, dan Wiko Saputra.2010, "Minang Entrepreneurship", Jakarta : Buduose Media.

Fayolle, Gailly, dan Lassas-Clerc. 2006. "Effect and Counter Effect of Entrepreneurship Education and Social Context on Student's Intentions," Estudios de Economia Aplicada. Vol. 24-2, pp 509-523.

Handriani, Eka. 2011, "PengembanganKualitas Pendidikan Kewirausahaan di PerguruanTinggi", JurnalImiahInkoma,Volume 22, No.1, pp.83-95.

Handaling, H. Sabil, "Mengefektifkan Fungsi Pendidikan Kewirausahaan Untuk Mengatasi Persoalan Mutu Perguruan Tinggi“, www.isjd.pdii.lipi.go.id/ admin/jurnal/1610642 56/pdf diakses pada 10/02/2019.

Heinonen, Jarna and Anne Poikkijoki, Sari. (2006). An Entrepreneurial-Directed Approach to Entrepreneurship Education: Mission Impossible? Journal of Management Development 25 (1): 80-94 
Kasih, Yulizar. 2013. "Mewujudkan Pendidikan Kewirausahaan Di Perguruan Tinggi Melalui Proses pembelajaranBerkelanjutan," JurnalIlmiah STIE MDP: Forum Bisnis dan Kewirausahaan2 (2): 164-181.

Kourilsky, M.L. \&Walstad, W.B.,(1998), Entrepreneurship and Female Youth: Knowledge, Attitudes, Gender Differences and Educational Practices. Journal of Business Venturing, 13(1): 77-88.

Murtini, W. 2011. Pendidikan KewirausahaanDenganPemodelanWirausaha. Jurnalllmu Pendidikan, Jilid 17, Nomor 5, Juni 2011, hal 401-410

Mulyana. S. 2014. PeningkatanKapabilitasInovasi, KeunggulanBersaing dan KinerjamelaluiPendekatanQuadruple Helix :Studi pada IndustriKreatifSektorFashion. JurnalManajemenTeknologi, Vol. 13, No. 3, 2014. Bandung: Research and Knowledge, School of Business and Management- InstitutTeknologi Bandung.

Nteere.K.K, Namusunge.G, Makulu.E. (2012). Pedagogical Approaches Determining the Performance of Entreprenurship Education in Kenya Public Universities. International Journal of Humanities and Social Science, Vol. 2 No. 13; July 2012, pp 238-246

Nwachuku, Emeka.(2018). Availability and Adequacy of Resources for Entrepreneurship Education in Universities in South-East, Nigeria, International Journal of Humanities and Social Science, Vol. 8, No. 11, November 2018, pp 127-138

PrilRanto, DW. 2016. "MembangunPerilaku Entrepreneur pada MahasiswaMelalui Entrepreneurship Education," JBMA, Vol.III, No.1, Maret,pp.79-86.

Saeid Karimi et al. 2016. "The Impact of Entrepreneurship Education: A Study of Iranian Students EntrepreneurialIntentions and Opportunity Identification." Journal of Small Business Management, Volume 54, Issue 1,Pp187-209.

Siswoyo.B.B. 2009. Pengembangan Jiwa Kewirausahaan di KalanganDosen dan Mahasiswa, JurnalEkonomiBisnis, Tahun 14, Nomor 2, Juli 2009: ,Balitbang, Kemdikbud.

Sukidjo. 2011. MembudayakanKewirausahaan. WUNY MajalahIlmiahPopulerTahun XII, Nomor1,Januari 2011. Yogyakarta: Universitas Negeri Yogyakarta.

Susilaningsih. 2012. "Konstruksi Model Program Pendidikan Kewirausahaan Di Perguruan Tinggi: PendekatanSequential Exploratory Mixed Research Design Berbasis Multi Kasus. Universitas Negeri Malang.” Disertasi. http://karya-ilmiah.um.ac.id/index.php /disertasi/article/view/18063

Suryana. 2006. KEWIRAUSAHAAN PedomanPraktis: Kiat dan Proses MenujuSukses. (edisi 3). Jakarta:SalembaEmpat.

Wiratno, S. 2012. Pelaksanaan Pendidikan Kewirausahaan di Perguruan Tinggi, Jurnal Pendidikan dan Kebudayaan, Vol 18, No.4, Desember 2012

Widjanarko, Pujiastuti, dan Santoso,"PembelajaranBerbasisInkubatorBisnisUntukMengembangkan Jiwa Kewiausahaan", http://repository.upnyk.ac.id/diakses pada 20/02/2019

Wibowo, A. 2017. Dampak Pendidikan KewirausahaanbagiMahasiswa, Asian Journal of Entrepreneurship and Family Business, Vol 1, No. 1

Wijaya, Tony, (2008), Kajian Model EmpirisPerilakuBerwirausaha UKM DIYdanJawa Tengah, JurnalManajemen dan Kewirausahaan, Vol.10, No. 2, September, Hal. 93-104.

Zimmerer, W. T. and Scarborough, M. N., (1996), Essentials of Entrepreneurship and Small Business Management.Prentice Hall: Third Edition 